\title{
Peran Work-Life Balance Terhadap Psychological Well-Being Pegawai yang Bekerja Selama New Normal Covid-19
}

\author{
Suli Sri Rejeki ${ }^{1}$, Fitria Rahmi ${ }^{2}$, Yantri Maputra ${ }^{3}$ \\ 1,2Universitas Andalas,Program Studi Psikologi; \\ email: *1sulisri58@gmail.com,
}

\begin{abstract}
Abstrak
Artikel INFO

Diterima:12 Juli 2021

Direvisi 05 Agustus 2021

Disetujui: 11 Oktober 2021

DOI:

http://dx.doi.org/10.24014/ jp.v14i2.13604

Covid-19 mempengaruhi kehidupan manusia yang membuat tatanan kehidupan manusia menjadi berubah, salah satunya adalah adanya perubahan budaya kerja dari WFH (Work From Home), WFO (Work From Office), dan keduanya. Hal ini mempengaruhi Work-life balance pegawai dalam kehidupan pribadi maupun kehidupan kerjanya. Tujuan dari penelitian ini adalah menguji apakah ada atau tidak pengaruh work-life balance terhadap psychological well-being pegawai yang bekerja selama new normal covid-19. Metode penelitian yang digunakan adalah metode kuantitatif berupa regresi linear sederhana dengan teknik puposive sampling dan jumlah sampel sebanyak 123 orang. Pengumpulan data dilakukan dengan menggunakan alat ukur yaitu Ryff Psychological Well-being Scale dan Skala Work-life Balance dari Fisher, Bulger, dan Smith (2009). Masing-masing skala memiliki reliabilitas sebesar .890 dan .821. Hasil penelitian menunjukkan bahwa work-life balance memiliki pengaruh yang signifikan terhadap psychological well-being yang dapat dilihat dari nilai signifikan $.001 \quad(P<.05)$ dan nilai koefisien R-square $\left(R^{2}\right)$ sebesar .094. Hal ini menunjukkan work-life balance memberikan kontribusi sebesar $9.4 \%$ terhadap psychological well-being pada pegawai yang bekerja selama new normal covid-19.
\end{abstract}

Kata kunci: Psychological Well-being, Work-life Balance, New Normal Covid-19

\begin{abstract}
Covid-19 affects human life which changes the order of human life, one of which is a change in the work culture of WFH (Work From Home), WFO (Work From Office), and both. This affects the work-life balance of employees in their personal and work lives. The purpose of this study is to test whether or not there is an effect of work-life balance on the psychological well-being of employees who work during the new normal covid-19. The research method used is quantitative with simple linear regression with purposive sampling technique, and the number of samples is 123 people. Data was collected using measuring instruments the Ryff Psychological Well-being Scale and the Work-life Balance Scale from Fisher, Bulger, \& Smith (2009). Each scale has a reliability of 890 and .821. The results of this study show that psychological well-being is significantly impacted by work-life balance which can be seen from the significance of $.001(P<.05)$ and the $R$-square coefficient $\left(R^{2}\right)$ of .094 . This shows that work-life balance contributes $9.4 \%$ to the psychological well-being of employees who work during the new normal covid-19.
\end{abstract}

Keywords: Psychological Well-being, Work-life Balance, New Normal Covid-19

\section{Pendahuluan}

Pada akhir tahun 2019 ditemukan virus di China yang disebut dengan corona virus disease (Covid-19). Awal tahun 2020, covid-19 telah melanda hampir seluruh dunia dan Indonesia adalah salah satu negara yang juga terkena virus tersebut. Dilansir dari laman kompas.com, pada 29 September 2020 pasien positif covid-19 di Indonesia mencapai 282.724 orang, terjadi pertambahan kasus sebanyak 4.002 dari hari sebelumnya (Nugraheny, 2020).

Pertengahan Maret 2020, pemerintah memberikan Surat Edaran Nomor 14/ SE/2020 terkait himbauan work from home yang disampaikan oleh Pimpinan Dinas 
Tenaga Kerja, Transmigrasi, dan Energi DKI Jakarta (Sari, 2020). Peringatan ini diberikan di Jakarta, namun setelah itu seluruh perkantoran di Indonesia melakukan work from home untuk pegawainya. Akibat covid-19, beberapa pegawai menyelesaikan semua kegiatan dari rumah dan bekerja dari rumah atau WFH (Wilder-Smith \& Freedman, 2020). Penerapan WFH di Indonesia bertujuan untuk mengurangi penyebaran Covid-19. Banyak organisasi di Indonesia yang tidak menggunakan WFH sebagai konsep utama atau budaya kerja, sehingga organisasi tidak siap untuk menjalankan WFH bagi pegawainya (Mustajab et al., 2020). Pegawai yang belum sepenuhnya memahami WFH mengalami dilema pada beberapa kondisi, misalnya tentang pola pikir bahwa rumah merupakan tempat untuk beristirahat dan berkumpul bersama keluarga, sedangkan kantor merupakan tempat untuk bekerja. Hal ini terkadang menimbulkan konflik dalam keluarga dan pekerjaan meskipun WFH menciptakan fleksibilitas waktu dan tempat (McCloskey, 2018).

Pola penurunan kasus covid-19 yang cukup lama membuat semua orang bersiap untuk beraktivitas di luar rumah dengan memperhatikan kaidah-kaidah kesehatan yang ketat mulai dari penggunaan masker, cuci tangan, physical distancing, dan lainya (Yuningsih, 2020). Kebiasan baru ini disebut juga dengan new normal, sesuai dengan penegasan Pemimpin Republik Indonesia Joko Widodo yang menyebut istilah new normal dengan tatanan baru untuk dapat berdampingan dengan covid-19 dan kehidupan dapat berjalan dengan memperhatikan protokol kesehatan yang telah ditetapkan (Habibi, 2020). Begitupun dengan klaster perkantoran terdapat dua sistem kerja yang diterapkan yaitu, tetap WFH atau WFO dengan menjalankan protokol kesehatan. Pelaksanaan sistem kerja dapat disesuaikan dengan fleksibilitas pengaturan kerja dimana pegawai dapat memilih mekanisme kerja antara WFH atau WFO, namun saat ini beberapa perkantoran di Indonesia sudah menerapkan WFO bagi pegawainya (Taufik \& Warsono, 2020). Akibatnya, kinerja pegawai tidak optimal dan memicu terjadinya stres bagi pegawai akibat lingkungan kerja yang tidak stabil (Muslim, 2020). Sesuai dengan Lazaruz (1966) tuntutan lingkungan merupakan salah satu sumber stres dan dapat mempengaruhi kesejahteraan psikologis (psychological wellbeing) seseorang.

Istilah psychological well-being digunakan untuk menggambarkan kesejahteraan seseorang sesuai dengan fungsi psikologi positif yang terdiri dari penerimaan diri, hubungan positifdenganoranglain, otonomi, penguasaan lingkungan, tujuan hidup, dan personal growth (Ryff, 1989). New normal selama pandemi Covid-19 membuat psychological well-being tergangggu karena banyaknya tuntutan dan peran yang harus dijalankan dalam satu atap pada pegawai yang menjalankan WFH. Hal ini ditandai dengan adanya peningkatan stres berupa sakit kepala, sakit maag, sulit berkonsentrasi, mudah marah, cemas, dan rendahnya tingkat kesejahteraan (Samakul \& Ruata, 2020). Sedangkan pada pegawai yang mulai menerapkan kembali WFO merasa cemas dan khawatir akan terkena covid-19, karena pegawai lain yang tidak displin dalam menerapkan protokol kesehatan (Muslim, 2020). Salah satu yang mempengaruhi psychological well-being adalah work-life balance. Sejalan dengan pendapat Parkes dan Langford (2008) bahwa work-life balance akan mempengaruhi psychological well-being pegawai, dengan asumsi ketika pegawai dapat memenuhi work-life balance maka akan dapat mencapai kepuasan dan kebahagiaan dalam hidup seperti psychological well-being yang baik, sehingga tercapai hubungan keluarga yang lebih erat. Sementara itu, ketidakseimbangan kehidupan pekerjaan merupakan salah satu dari 13 faktor psikososial yang berkaitan dengan rendahnya tingkat kesejahteraan 
pegawai. Akibatnya, bentrokan antara pekerjaan dan keluarga mempengaruhi worklife balance dan psychological well-being (Dirfa \& Prasetya, 2019).

Work-life balance merupakan pengalaman yang saling bersinergi antara keluarga dan pekerjaan agar kualitas keduanya meningkat, serta kaitannya dengan menggabungkan antara keluarga di tengah-tengah lingkup organisasi sehingga mampu menemukan makna dan keterikatan pegawai (Kishino \& Hirano, 2016). Pandemi Covid-19 membuat semua anggota keluarga tidak dapat beraktivitas di luar rumah dan anak-anak tidak bersekolah sehingga membutuhkan pengelolaan ruang kerja dan manajemen waktu yang baik agar tetap terjaga work-life balance atau keseimbangan antara kehidupan pribadi dan pekerjaan (Kaushik \& Guleria, 2020). Menurut Galea, et al., (2020) batasan waktu antara pekerjaan kantor dan pekerjaan rumah tangga yang minim serta kurangnya interaksi sosial menyebabkan pegawai mendapatkan konsekuensi pada kesehatan mental dan keseimbangan kehidupan pegawai, baik jangka pendek maupun jangka panjang yang membuat pegawai di Indonesia menanggapi secara negatif kebijakan $\mathrm{WFH}$, terutama pada pegawai yang sudah menikah (Hapsari, 2020). Sejalan dengan hasil penelitian yang dilakukan oleh Maria \& Nurwati (2020) bahwa dari 175 responden, $40.3 \%$ merasa tidak semua pekerjaan bisa dilakukan di rumah, $43.4 \%$ mengatakan WFH mendorong peningkatan pengeluaran fungsional keluarga, dan sisanya $27.3 \%$ menunjukkan berkurangnya inspirasi karena jam tidur yang sporadis, dan kesulitan untuk fokus pada anak-anak, serta sering terjadi miskomunikasi dengan rekan kerja. Selain itu, Konflik juga dapat terjadi karena adanya kepentingan-kepentingan yang berlawan, yaitu apakah harus tetap menjalani WFH atau WFO (Muslim, 2020). Pada beberapa hasil penelitian terdahulu seperti penelitian yang dilakukan oleh Keene dan Quadagno (2004) menunjukan bahwa keseimbangan juga sulit dicapai pada pasangan bekerja dan memiliki anak di bawah usia 18 tahun.

Pada survei Panel Studi Sosial Covid-19 terbaru yang dilansir dari laman kompas. com, pada tanggal 25 Mei 2020 menunjukkan bahwa 10,2\% mengalami dampak secara psikologis dengan gejala yang serius dan banyak dialami oleh kelompok usia produktif selama new normal (Idris, 2020). Oleh karena itu, peneliti tertarik untuk meneliti adanya pengaruh work-life balance terhadap psychological well-being pada pegawai yang bekerja selama new normal covid-19.

\section{Metode}

Jenis Penelitian

Penelitian ini menggunakan pendekatan kuantitatif dengan metode penelitian korelasional. Pendekatan kuantitatif menekankan analisisnya pada data-data angka yang diolah dengan metode statistik (Azwar, 2017). Variabel yang digunakan dalam penelitian ini adalah work-life balance dan psychological well-being.

\section{Subjek Penelitian}

Penelitian ini dilakukan di Kota Padang, Sumatera Barat. Teknik pengambilan sampel yang digunakan dalam penelitian ini non-probability sampling dengan bentuk purposive sampling. Non-probability sampling adalah teknik pengambilan sampel dimana besarnya peluang anggota dari populasi untuk dipilih tidak diketahui (Azwar, 2017). Puposive sampling didefenisikan sebagai teknik sumber data dengan pertimbangan tertentu (Sugiyono, 2010). Adapun kriterianya adalah: pegawai yang bekerja selama new normal Covid-19 berdasarkan kebijakan dari pemerintah untuk mengurangi tingkat penyebaran Covid-19 (WFH, WFO, atau WFH dan WFO), telah menikah, dan memiliki anak usia di bawah 18 tahun. Partisipan dalam 
penelitian ini berjumlah 123 pegawai yang terdiri dari 34 pegawai laki-laki dan 89 pegawai perempuan, dengan usia pada dewasa awal (20-40 tahun) berjumlah 108 pegawai dan dewasa madya (41-60 tahun) berjumlah 15 pegawai, pegawai yang memiliki pasangan bekerja sebanyak 108 pegawai dan yang memiliki pasangan tidak bekerja sebanyak 15 pegawai, dan pegawai yang bekerja dengan sistem WFH sebanyak 21 pegawai, WFO sebanyak 34 pegawai, serta WFH dan WFO sebanyak 68 pegawai.

\section{Pengukuran}

Psychological well-being dari Ryff. Skala psychological well-being yang digunakan dalam penelitian ini merupakan alat ukur yang diadaptasi oleh Engger (2015) dari Ryff Psychological Well-being Scale. Skala ini telah diuji coba dan menghasilkan reliabilitas ( $\alpha$ ) sebesar .935. Pada penelitian ini, peneliti melakukan pengujian reliabilitas dan daya diskriminasi dari 84 item dihasilkan reliabilitas $(\alpha)$ sebesar .930. Penentuan daya diskriminasi item sesuai dengan Azwar (2015) Koefisien korelasi yang diatas .25 dapat dikatakan memiliki uji daya item dikatakan memuaskan dan jika koefisien dibawah .25 dikatakatan memiliki uji daya beda item kurang memuaskan. Dalam penelitian ini dihasilkan 63 item $\geq .25$ dengan koefisien Cronbach Alpha ( $\alpha$ ) sebesar .890, salah satunya item nomor 6 yang berbunyi "saat saya melihat sejarah hidup saya, saya merasa senang atas segala hal yang terjadi".

Work-life Balance dari Fisher, Bulger, \& Smith (2009).Skala work-life balance yang digunakan dalam penelitian ini merupakan alat ukur yang diadaptasi oleh Gunawan, et al., (2019) sesuai dengan skala yang dikembangkan oleh Fisher, et al., (2009). Skala work-life balance ini terdiri dari 4 dimensi yaitu, WIPL (work interference with personal life), PLIW (personal life interference with work), WEPL (work enhancement of personal work), dan PLEW (personal life enhancement of work). Pada penelitian ini, penelitian melakukan pengujian reliabilitas dan daya diskriminasi dari 17 item dihasilkan reliabilitas $(\alpha)$ sebesar .821 . Penentuan daya diskriminasi item sesuai dengan Azwar (2015) Koefisien korelasi yang diatas .25 dapat dikatakan memiliki uji daya item dikatakan memuaskan dan jika koefisien dibawah .25 dikatakatan memiliki uji daya beda item kurang memuaskan. Dalam penelitian ini dihasilkan 17 item $\geq .25$ yang artiya tidak terdapat item gugur, salah satunya item nomor 13 yang berbunyi "karena pekerjaan saya, saya memiliki suasana hati yang lebih baik di rumah".

\section{Analsis Data}

Teknik analisis data dalam penelitian ini adalah regresi linear sederhana. Reliabilitas meggunakan Alpha Cronbach, uji normalitas dengan menggunakan Kolmogorov-Smirnov, uji linearitas menggunakan Test for Linearity. Analisis data dilakukan dengan menggunakan bantuan SPSS 16.0 for windows.

\section{Hasil}

Berdasarkan hasil Kolmogorov-Smirnov diperoleh nilai signifikansi untuk kedua variabel sebesar .075 ( $p>.05)$, maka dapat dikatakan bahwa data terdistribusi secara normal (Azwar, 2020). Berdasarkan hasil uji linearitas diketahui variabel work-life balance dengan psychological well-being memiliki hubungan yang linear dengan signifikansi sebesar .001 ( $p$ <.05) (Priyatno, 2013). Variabel psychological well-being dengan work-life balance memiliki korelasi yang signifikan ditunjukan dengan nilai signifikansi sebesar $.001(p<.05)$. Kemudian hasil data deskriptif menunjukan secara umum psychological well-being pegawai yang bekerja selama new normal covid-19 cukup bervariasi ( $M=277.12$; $S D=26.02$ ), dimana pegawai telah mampu menjalin hubungan yang positif dengan orang lain dan memiliki environmental mastery yang baik. 
Tabel 1. Analisis Deskriptif Setiap Variabel Penelitian

\begin{tabular}{|c|c|c|c|c|}
\hline Variabel & $\begin{array}{c}\text { Skor } \\
\text { Minimum }\end{array}$ & $\begin{array}{c}\text { Skor } \\
\text { Maksimum }\end{array}$ & Mean & $\begin{array}{l}\text { Standar } \\
\text { Deviasi }\end{array}$ \\
\hline Psychological Well-being & 195 & 352 & 277.12 & 26.02 \\
\hline Self Acceptence & 22 & 47 & 34.86 & 4.63 \\
\hline $\begin{array}{l}\text { Positive Relation with } \\
\text { Other }\end{array}$ & 34 & 64 & 52.58 & 6.26 \\
\hline Environmental Mastery & 32 & 72 & 52.58 & 6.55 \\
\hline Autonomy & 29 & 54 & 38.91 & 4.41 \\
\hline Purpose in Life & 27 & 53 & 41.62 & 11.94 \\
\hline Personal Growth & 30 & 59 & 47.13 & 4.66 \\
\hline Work-life Balance & 42 & 79 & 61.65 & 6.65 \\
\hline WIPL & 10 & 25 & 18.53 & 2.71 \\
\hline PLIW & 12 & 30 & 21.99 & 3.19 \\
\hline WEPL & 3 & 15 & 9,93 & 1.75 \\
\hline PLEW & 5 & 15 & 11,19 & 2.13 \\
\hline
\end{tabular}

Berdasarkan hasil uji regresi linear sederhana menunjukan bahwa nilai signifikansi antara pengaruh work-life balance terhadap psychological well-being pada pegawai yang bekerja selama new normal covid-19 yaitu sebesar .001 $(p<.05)$, maka dapat disimpulkan bahwa work-life balance memiliki pengaruh yang signifikan terhadap psychological well-being. Kemudian, dari hasil perhitungan diperoleh nilai R-square $\left(R^{2}\right)$ sebesar 094 (9.4\%). Hal ini menunjukan bahwa variabel bebas yaitu work-life balance memiliki pengaruh terhadap variabel terikat yaitu psychological well-being sebesar $9.4 \%$, sedangkan $90.6 \%$ lainya dipengaruhi oleh faktor lain.

Selanjutnya persamaan regresi yang didapatkan adalah $\mathrm{Y}=203.365+1.198 \mathrm{X}$. Dari persamaan tersebut dapat diketahui bahwa konstanta sebesar 203.26, artinya saat work-life balance 0 maka psychological wellbeing memiliki nilai 203.365. Kemudian pada tabel B menunjukkan bahwa ketika terjadi penambahan satu satuan skor pada variabel work-life balance, maka psychological well-being akan bertambah sebesar 1.198 sehingga dapat disimpulkan bahwa semakin tinggi work-life balance maka akan semakin tinggi pula psychological well-being.

\section{Pembahasan}

Berdasarkan hasil uji regresi linear sederhana, menunjukan bahwa terdapat pengaruh antara work-life balance terhadap psychological well-being pegawai yang bekerja selama new normal covid-19. Tingkat signifikansi kedua variabel adalah .001 yang lebih kecil dari .05 , artinya bahwa terdapat pengaruh antara work-life balance dan psychological well-being pegawai.

Ada beberapa penelitian sebelumnya yang mendukung penelitian ini, diantaranya adalah penelitian yang dilakukan oleh Hoffmann-Burdzinska \& Rutkowska (2015) yang menyatakan bahwa psychological wellbeing seseorang dipengaruhi oleh work-life balance. Penelitian serupa juga dilakukan oleh Parkes \& Langford (2008) yang menunjukkan antara work-life balance dan psychological well-being memiliki pengaruh yang signifikan. Terpenuhinya work-life balance membuat pegawai mencapai kepuasan dalam hidup, psychological well-being menjadi lebih baik, serta hubungan dengan keluarga semakin erat.

Besarnya pengaruh variabel work-life balance terhadap psychological well-being pegawai yang bekerja selama new normal 
covid-19 yaitu sebesar $9.4 \%$, sedangkan $90.6 \%$ lainya dipengaruhi selain work-life balance. Kontribusi pengaruh work-life balance terhadap psychological well-being yang sangat rendah disebabkan adanya faktor lain yang tidak diteliti oleh peneliti. Pada penelitian ini pegawai yang bekerja selama new normal covid-19 didominasi oleh pegawai yang bekerja dengan menggunakan sistem WFH dan WFO yaitu sebanyak 68 pegawai, perubahan sistem kerja akibat pandemi covid-19 membuat pegawai harus cepat belajar dan beradaptasi dengan perubahan yang tidak menentu. Muslim (2020) perubahan kondisi kerja dengan sistem WFH dan WFO membuat kinerja pegawai menjadi tidak optimal dan memicu terjadinya stres dan kecemasan bagi pegawai, yang memberikan efek merugikan untuk kesehatan mental dan membuat psychological well-being menurun (Kang et al., 2020; Mukhtar, 2020; Pakpour \& Griffiths, 2020; Taylor et al., 2020).

Selanjutnya, perubahan yang terjadi selama pandemi covid-19 membuat pegawai harus beradaptasi dengan pola kerja baru dimana memberikan tantangan tersendiri bagi pegawai terutama pegawai yang memiliki pasangan bekerja. Menurut Efi \& Parahyanti (2021) pegawai yang memiliki pasangan bekerja memiliki tanggung jawab dalam pekerjaan dan keluarga yang harus dipenuhi, sehingga berbagai tuntutan dan peran yang dihadapi bersama dapat mengancam psychological well-being pegawai di masa pandemi covid-19, selain itu pegawai yang memiliki anak bertanggung jawab dalam pengasuhan dan pendampingan, akibat sekolah dan layanan perawatan yang tidak beroperasi dengan maksimal (Perdana et al., 2020). Adanya tuntutan dan permasalahan baru ini membuat peran antara pekerjaan dan keluarga semakin samar, akibatnya mempertahankan batasan antara pekerjaan dan keluarga semakin sulit (Giuerge \& Bohns, 2020). Hal ini sejalan dengan penelitian yang dilakukan oleh Poulose \& Sudarsan (2014) peran pekerjaan dan keluarga menjadi tidak seimbang sebagai akibat dari tugas pengasuhan anak.

Pada penelitian ini menunjukan bahwa pegawai yang memiliki pasangan bekerja sebanyak 108 orang, sedangkan yang memiliki pasangan tidak bekerja sebanyak 15 orang. Hal ini menandakan bahwa subjek penelitian didominasi oleh pegawai dengan pasangan yang bekerja. Penelitian yang dilakukan oleh Waite dan Gallagher (2000) menunjukan bahwa ketika pasangan suami istri bekerja membuat konflik dan ketegangan akan meningkat. Pekerjaan dan keluarga merupakan area yang berbeda pada kehidupan seseorang yang harus dipenuhi. Pasangan suami istri yang bekerja lebih sulit dalam mengatur kehidupan rumah tangga dibandingkan dengan kehidupan rumah tangga tradisional dimana suami bekerja dan istri di rumah (Howard, et al., 2004). Sejalan dengan penelitian Allen, et al., (2000) pasangan suami istri yang berkarir dan memiliki anak, bertanggung jawab terhadap rumah dan keluarganya. Dengan demikian tanggung jawab dalam pekerjaan, rumah tangga, dan pengasuhan anak menjadi berat dan berakibat tidak tercapainya work-life balance pegawai (Razak et al., 2011).

\section{Kesimpulan}

Hasil penelitian menunjukan bahwa terdapat pengaruh yang signifikan antara work-life balance terhadap psychological well-being pada pegawai yang bekerja selama new normal covid-19 di Kota Padang. Secara umum dapat dilihat bahwa work-life balance pada pegawai yang bekerja selama new normal covid-19 di Kota Padang dalam kategori sedang, artinya pegawai yang bekerja selama new normal covid-19 di Kota Padang yakin bahwa dirinya dapat berhasil melakukan setiap tugas dan perannya dengan baik, antara kehidupan pekerjaan dan kehidupan pribadi atau keluarga. namun belum semua pegawai merasakan 
hal tersebut. Pegawai yang bekerja selama new normal covid-19 di Kota Padang secara umum memiliki psychological well-being dalam kategori tinggi, artinya pegawai telah mampu mengelola psychological well-being nya selama bekerja di masa new normal covid-19.

Bagi organisasi diharapkan dapat menjalankan program-program yang dapat memunculkan work-life balance pegawai, yaitu menerapkan sistem kerja yang menguntungkan baik pada organisasi atau pegawai, dan mendorong semangat pegawai. Organisasi juga dapat melakukan pendekatan kepada pegawai agar pegawai merasa lebih nyaman di lingkungan kerjanya dan tercipta lingkungan yang positif, hubungan antara pegawai dan organisasi menjadi erat, serta pegawai lebih terbuka kepada organisasi tentang permasalahan keluarganya. Kemudian diharapkan pada pegawai untuk lebih memperhatikan keseimbangan antara kehidupan pribadi dan kehidupan pekerjaan, dengan cara menjaga komunikasi baik antara rekan kerja maupun keluarga dan memaksimalkan waktunya dengan baik ketika di rumah ataupun di pekerjaan.

\section{Daftar Pustaka}

Allen, T., Herst, D., Burck, C., \& Sutton, M. (2000). Consequences associated with work-to-family conflict: A review and agenda for future research. Journal of Occupational Health Pychology, 5, 278-308. https://doi.org/10.1037/10768998.5.2.278

Azwar, S. (2015). Penyusunan skala psikologi (Edisi 3). Pustaka Belajar.

Azwar, S. (2017). Metode penelitian psikologi (Edisi 2). Pustaka Belajar.

Azwar, S. (2020). Dasar-dasar psikometri. Pustaka Belajar.

Dirfa, Y. N., \& Prasetya, B. E. A. (2019). Hubungan work-life balance dengan psychological well-being pada dosen wanita di perguruan tinggi salatiga.
Jurnal Psikohumanika, 11(2), 151-169.

Efi, G. O., \& Parahyanti, E. (2021). Predictors of workplace well-being for dual-earner couples during covid-19 pandemic. Gadjah Mada Journal of Psychology, 7(1), 33-47.

Engger. (2015). Adaptasi Ryff Psychological Well-being dalam konteks Indonesia. [Skripsi thesis, Sanata Dharma University]. Jogja Library. http://www. library.usd.ac.id//web/index.php?pilih $=$ search $\& p=1 \& q=126146 \& g o=$ Detail.

Fisher, G. G., Bulger, C. A., \& Smith, C. S. (2009). Beyond work and family: a measure of work/ nonwork interference and enhancement. Journal of Occupational Health Psychology, 14(4), 441. https://psycnet.apa.org/ doi/10.1037/a0016737

Galea, S., Merchant, R. M., \& Lurie, N. (2020). The mental health consequences of COVID-19 and physical distancing: The need for prevention and early intervention. JAMA Internal Medicine, 180(6), 817-818.

Giurge, L. M., \& Bohms, V. K. (2020, April 3). 3 tips to avoid WFH burnout. Retrieved April 13, 2020, from https:// hbr.org/2020/04/3-tips-to-avoid-wfhburnout

Gunawan, G., Nugraha, Y., Sulastiana, M., \& Harding, D. (2019). Reliabilitas dan validitas konstruk work life balance di Indonesia. JPP Jurnal Penelitian dan Pengukuran Psikologi, 8(2), 88-94. https://doi.org/10.21009/JPPP.082.05

Habibi, A. (2020). Normal baru pasca covid 19. 'ADALAH, 4(1). https://doi.org/10.15408/ adalah.v4i1.15809

1Hapsari, I. (2020). Konflik peran ganda dan kesejahteraan psikologis pekerja yang menjalani work from home pasca pandemi COVID-19. Jurnal Psikologi, 13(1), 37-45. https://doi.org/10.35760/ psi.2020.v13i1.2623

Hoffmann-Burdzińska, K., \& Rutkowska, M. (2015). Work life balance as a factor 
influencing well-being. Journal of Positive Management, 6(4), 87-101. http://dx.doi.org/10.12775/JPM.2015.024

Howard, W.G., Donofrio, H. H., \& Boles, J. S. (2004). Inter-domain work-family, familywork conflict and police work satisfaction. Policing: An International Journal of Police Strategies \& Management, 27(3), 380-395.

Idris, M. (2020, Mei 25). Aturan new normal: Jarak antar karyawan di kantor minimal 1 meter". https://www.google. com/amp/s/amp.kompas.com/money/ read/2020/05/25/070800626/aturan-newnormal-jarak-antar-karyawan-di-kantorminimal-1-meter

Kang, L., Li, Y., Hu, S., Chen, M., Yang, C., Yang, B. X., Wang, Y., Hu, J., Lai, J., Ma, X., Chen, J., Guan, L., Wang, G., Ma, H., \& Liu, Z.. (2020). The mental health of medical workers in Wuhan, China dealing with the 2019 novel corona virus. The Lancet Psychiatry, 7(3), e14

Kaushik, M., \& Guleria, N. (2020). The impact of pandemic COVID-19 in workplace. European Journal of Business and Management, 12(15), 1-10. http://dx.doi. org/10.7176/EJBM/12-15-02.

Keene, J. R., \& Quadagno, J. (2004). Predictors of perceived work-family balance: Gender difference or gender similarity?. Sociological Perspectives, 47(1), 1-23.

Kishino, S., \& Hirano, M. (2016). The effect of supervisors' transformational leadership on subordinates' psychological empowerment and work-life balance. http://www.lib.kobe-u.ac.jp/ handle kernel/81009393.

Lazarus, R. S. (1966). Psychological stress and the coping process. McGraw-Hill.

Maria, G. A. R., \& Nurwati, N. (2020). Analisis pengaruh peningkatan jumlah masyarakat terkonfirmasi covid-19 terhadap produktivitas penduduk yang bekerja di Jabodetabek. Fokus: Jurnal
Pekerjaan Sosial, 3(1), 1-15. https://doi. org/10.24198/focus.v3i1.28116.g13682

McCloskey, D. W. (2018). An examination of the boundary between work and home for knowledge workers. International Journal of Human Capital and Information Technology Professionals (IJHCITP), 9(3), 25- 41. http://dx.doi. org/10.4018/IJHCITP.2018070102

Mukhtar, S. (2020). Psychological health during the coronavirus disease 2019 pandemic outbreak. International Journal of Social Psychiatry, 66(5), 512-516. https://doi. org/10.1177/0020764020925835.

Muslim, M. (2020). Manajemen stress pada masa pandemi covid-19. ESENSI: JurnalManajemenBisnis, 23(2), 192-201. Mustajab, D., Bauw, A., Rasyid, A., Irwan, A., Akbar, M. A., \& Hamid, M. A. (2020). Working from home phenomon as an effort to prevent covid-19 attacks and its impact on work productivity. The International Journal of Applied Business (TIJAB), 4(1), 13.

Nugraheny, D. E. (2020, September 29). Update 29 september: tambah 3.567, pasien covid-19 sembuh kini 210.437 orang". Kompas.com. https://www. google.com/amp/s/amp.kompas.com/ nasional/read/2020/09/29/15325571/ update-29-september-tambah-3567pasien-covid-19-sembuh-kini-210437orang.

Pakpour, A. H., \& Griffiths, M. D. (2020). The fear of COVID-19 and its role in preventive behaviors. Journal of Concurrent Disorders, 2(1), 58-63.

Parkes, L. P., \& Langford, P. H. (2008). Worklife balance or work-life alignment? A test of the importance of work-life balance for employee engagement and intention to stay in organisations. Journal of Management \& Organization, 14(3), 267-284. https://doi.org/10.5172/ jmo.837.14.3.267

Perdana, R. C., Agustino, M. R., Hartawan, 
D., Suyoso, Y. A., \& Sari, R. (2020). Adaptasi dan kebiasaan baru human resource department di masa pandemic covid-19. Business Innovation and Entrepreneurship Journal, 2(3), 201204. https://doi.org/10.35899/biej. v2i3.138

Poulose, S., \& Sudarsan, N. (2014). Work life balance: A conceptual review. International Journal of Advances in Management and Economics, 3(2), 1-17.- 21. http://dx.doi.org/10.20473/tijab. V4.I1.2020.13-21

Priyatno, D. (2013). Analisis korelasi, regresi dan multivariate dengan SPSS (Edisi 1). Gava Media.

Razak, A. Z. A. A., Yunus, N. K. Y., \& Nasarudin, A. M. (2011). The impact of work overload and job involvement on work-family conflict among Malaysian doctors. Labuan e-Journal of Muamalat and Society, 5, 1-10.

Ryff, C. D. (1989). Happiness is everything, or is it? Exploration on the meaning of psychological well-being. Journal of Personality and Social Psychology, 57(6), 1069.

Samakul, Y., \& Ruata, S. (2020). Kesejahteraan psikologis dalam masa pandemi COVID-19. Journal of Psychology" Humanlight", 1(1), 1-7.

Sari, N. (2020, September 29). Cegah covid-19, pemprov DKI imabau perusahaan terapkan kerja dari rumah". Kompas. com. https://www.google.com/amp/s/ amp.kompas.com/megapolitan/read/ 2020/03/16/12265131/cegah-covid-19pemprov-dki-imbau-perusahaan-terapkankerja-dari-rumah.

Sugiyono. (2010). Metode penelitian kuantitatif, kualitatif dan $R \& D$. Alfabeta.

Taylor, S., Landry, C. A., Paluszek, M. M., Fergus, T. A., McKay, D., \& Asmundson, G. J. (2020). Development and initial validation of the COVID Stress Scales. Journal of Anxiety Disorders,
72, 102232. https://doi.org/10.1016/j. janxdis.2020.102232

Taufik, T., \& Warsono, H. (2020). Birokrasi baru untuk new normal: Tujuan model perubahan birokrasi dalam pelayanan publik di era covid-19. Dialogue: Jurnal IImu Adminitrasi Publik, 2(1), 1- 8. https://doi.org/10.14710/dialogue. v2i1.8182

Waite, L., \& Gallaher, M. (2000). The case for marriage: Why married people are happier, healthier and better off financially (1th ed). Doubleday

Wilder-Smith, A., \& Freedman, D. O. (2020). Isolation, quarantine, social distancing and community containment: Pivotal role for old-style public health measures in the novel coronavirus (2019-nCoV) outbreak. Journal of Travel Medicine, 27(2). https://doi.org/10.1093/jtm/taaa020

Yuningsih, R. (2020). Promosi kesehatan pada kehidupan new normal pandemi covid-19. Info Singkat 12(11). 